\section{O-129 覀性胸膜中皮腫の治療成績後上のための土}

\author{
九州大学大学院 消化器·総合外科
}

山口 正史，吉野 一郎，田川 哲三，龟山 敏文，小副川 敦, 米谷 卓郎, 饒平名 知史, 前原 喜彦

【背景】悪性胸膜中皮腫は局所進行性の疾患であり標準的治療法はな いが，近年 I期，上皮型では胸膜外肺全摘 (EPP)，化学・放射線療法 による集学的治療での予後の改善が報告されている。【目的】当科にお ける最近の悪性胸膜中皮腫 6 例に対寸る治療について検討した。【対 象·方法】 6 症例の平均年齢は 57 歳, 男性 5 名, 女性 1 名. 病理病期 はI期拉よびN2によるIII 期が各 3 例で，全例が上皮型であった。全 例に胸膜外肺全的術を施行し, この際に局所制御を目的に術中 hypotonic CDDP 療法を施行した。このうち 1 例に術前および術後化 学療法 $(\mathrm{CDDP}+\mathrm{GEM}+\mathrm{VNR})$ を, 4 例に術前化学療法 (CDDP + CPT-11 1 例, CDDP + GEM + VNR 3 例）を, また 1 例に術後化学 療法 (CDDP + GEM + UFT) を施行した。【結果】全 6 例とも術後 は胸水中に腫瘍細胞を認めなかった. 2 例に術後一過性の心房細動を 認めた他, 特記すべき周術期合併症を認めなかった。術後中央生存期 間は 22 ヶ月で 3 例については各 $16 ， 35 ， 36$ ヶ月間無再発生存中であ る. N2の 3 例中 1 例が術後 16 ケ月目に対側肺転移で再発し術後 20 ケ 月現在化学療法中であり，1例が術後 6 ケ月目に多発肺転移を来たし 化学療法を施行したが術後 24 ケ月目に腫瘍の進行による呼吸不全で 死亡した。1 例は術後 6 ケ月目縦隔りンパ節再発を認め, 放射線治療 中である．胸壁など胸膜剥離側における再発を認めなかった！結語】 胸膜外肺全的術と術中 Hypotonic CDDP 療法の併用は悪性胸膜中皮腫 の局所制御法の一つとして期待されるが，対側肺転移などに対する全 身的制御も必要であると考えられる。

\section{0-131}

PET-CTによるVirtual 縦隔鏡

${ }^{1}$ 国立がんセンター東病院 呼吸器科, ${ }^{2}$ 国立がんセンター東病院 放 射線科

似鳥 純一 ${ }^{1}$, 西村 光世 ${ }^{1}$, 村上 康二 ${ }^{2}$, 望月 孝裕 $^{1}$, 西條 天基 ${ }^{1}$, 今野 秀洋 ${ }^{1}$, 萩原 優 ${ }^{1}$, 菱田 智之 ${ }^{1}$, 吉田 純司 $^{1}$, 永井 完治 ${ }^{1}$

【背景】肺癌症例のリンパ節転移は重要な予後因子で, 特に縦隔りン パ節に転移を認めるか否かは，手術適応，術前・術後治療，予後を考 える上で特に重要である.PET-CT は PET と CT を組み合わせること により正確な解剖学的な位置, 転移病巣の検出が可能で, 臨床病期の 診断，再発診断など臨床への応用が期待されている.Virtual 縦隔鏡は PET-CT で得られた情報を 3 次元的に画像処理することにより，目的 のリンパ節生検の位置を正確に把握することができる。また，リンパ 節周囲の縦隔臟器の位置も確認できるためより安全に縦隔鏡が施行可 能となる新しい映像である。【目的】Virtual 縦隔鏡と縦隔鏡を比較検 討し，従来よりも安全かつ正確に標的とするリンパ節を生検すること を目的とした【対象および方法】CTにて縦隔リンパ節の短径が $10 \mathrm{~mm}$ 以上で, PET-CTにて同部位に hot spot を認める症例を対象と したＰPET-CTは米国 GE Healthcare 社製の Discovery LSを使用した。 CTは8列の多検出器型 CTであり, ダイナミックCTを施行した。【結 果】Virtual 縦隔鏡で術前に確認した様に前頝部より気管固有鞘下に縦 隔鏡を挿入し，気管前面を剥離し目標としたリンパ節を安全に生検で きた。【まとめ】 PET-CT は CTによる解剖学的に正確な位置の同定と PETによる代謝機能の描出が可能で，今後の肺癌治療方針の決定に有 用な診断装置である.PET-CTを用いたVirtual 縦隔鏡により縦隔りン パ節生検が安全で正確に施行できた。

$0-130$

呼吸器外科手術症例における PET 検査の有用 性に関する検討およびPET-CT 画像の紹介

\author{
1 名古屋共立病院 外科, ${ }^{2}$ 刈谷総合病院
}

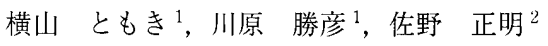

【背景】肺腫瘤において良悪性はもちろん, 肺癌に限っても治療法の 選択に $\mathrm{N} \cdot \mathrm{M}$ 因子の診断は重要で，正確な診断が望まれる。PETは良 悪性の鑑別·stage 診断に高い診断精度が報告されており，その有用性 について検討.【対象】H14.4月より H16.11月までに病理診断のつい た27 例. 46-79 歳, 男女比 17:10. 小細胞癌 2 例, 低分化腺癌 4 例, 低 分化扁平上皮癌 3 例, 中分化腺癌 5 例, 中分化扁平上皮癌 2 例, 高分 化腺癌 4 例, 高分化扁平上皮癌 2 例, 直腸癌肺転移 1 例, 結核腫 3 例, 胸 腺腫 1 例.【結果】原発性肺癌 10.19 (SURmax), 直腸癌肺転移例 2.81, 結核 3.01 , 胸腺腫 5.84 と肺癌で高い傾向. 分化度別では，小細胞癌 20.83 (SURmax), 低分化癌 15.86, 中分化癌 9.96, 高分化癌 3.96 と 未分化癌ほど有意に高値. 組織型別では差を認めず. N 因子診断能を PET/CT で比較. sesitivity $80 / 40 \%$ (PET/CT), specificity $100 / 83 \%$, negative predictive value $75 / 46 \%$, positive predictive value $100 / 80 \%$, over all accuracy $88 / 56 \%$ と PETの方が良好.【結語】1.PETは未分化癌 ではより高集積であり生物学的恵性度をよく反映. 2. 炎症性疾患で も陽性となり分化度の高い肺癌との鑑別は困難. 3.PETはN 因子の 診断能においてCTより優れている.4.PETはM 因子の診断能におい て脳転移以外は他の検査より優れており腹部 CT 骨シンチ検査の省 略ができる可能.【PET-CT】当院には H16.3月より本邦初の PET-CT が導入されている. PET-CT は PET 画像を CT 画像と fusion させ, 解 剖学的位置関係を的確に評価することができる。また，PET-CTでは CTによる 1 分間の transmisssion でよいため, scan に要す時間は従来 の $2 / 3$ ですみ, 患者の負担も軽減され, 今後 PET-CT の普及が予想さ れる。このPET-CT 画像を供覧する.

\section{$0-132$}

術前導入放射線化学療法を施行した $\mathrm{cN} 2$ 非小細 胞肺癌症例における FDG-PET の検討
1 香川大学 医学部 第二外科, 2 香川大学 医学部 放射線科

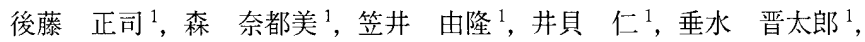
張 性洙 ${ }^{1}$, 中野 淳 ${ }^{1}$, 三崎 伯幸 ${ }^{1}$, 桝屋 大輝 ${ }^{1}$, 中島 尊 ${ }^{1}$,

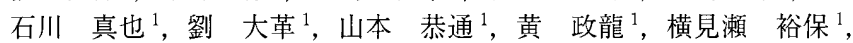
山本 由徍 ${ }^{2}$

【日的】術前導入放射線化学療法を施行した $\mathrm{cN} 2$ 非小細胞肺癌症例に おいて,FDG-PETによる効果判定の有用性を検討した。【対象と方 法】 2003 年 1 月から 2004 年 8 月まで導入療法後, 手術を行った $\mathrm{cN} 2$ 非小細胞肺癌 14 例を対象とした。CT で短径 $2 \mathrm{~cm}$ 以上のリンパ節腫大 を $\mathrm{cN} 2$ とした。導入療法は, 化学療法 (タキサンーカルボプラチン) 及び放射線療法（原発巣・縱隔に50Gy）を concurrent に施行した。治 療前後にCT 及び FDG-PET で評価した。手術は肺葉切除又は肺全摘 （ND2a）を施行した．CT, FDG-PET の所見と組織学的治療効果を比 較検討した.【結果】CTによる導入療法の治療効果判定はPR6例, SD8 例であった．組織学的治療効果は EF1b が 3 例, Ef2 が 10 例, Ef3 が 1 例であった，Ef1b 症例の導入療法による縮小率は $24.2 \%, \mathrm{SUV}$ 值の 減少率は $49.7 \%$ であった. Ef2 以上の症例の縮小率は $43.7 \%, \mathrm{SUV}$ 值 の減少率は $71.4 \%$ であった。術後病理で縦隔りンパ節に vivid な腫瘍 細胞を認めた 4 例の SUV 值は $5.80 て ゙ ，$ 何れも縦隔プールより濃い集 積を認めた。術後病理で vivid な腫瘍を認めなかった症例の SUV 值は 2.54 であった. SUV 值 2.50 cutoff とした際の, 縦隔リンパ節の尊 入療法後の評価は, 感度が 1.00 , 特異度は 0.50 で, 視覚的評価によ る判定の感度は 0.75 , 特異度は 0.90 であった、【結論】原発巣は, FDG-PETによって導入療法の効果が判定できる可能性がある。縦隔 リンパ節は, CT と FDG-PETの評価を組み合わせることで導入療法の 効果を判定出来る可能性がある. 